\title{
Ruminations on Karl Brunner's Reflections
}

\author{
Alan S. Blinder \\ PRINCETON UNIVERSITY
}

\section{Introduction}

Karl Brunner's mammoth paper is a wide-ranging and detailed survey and evaluation of many issues that are tied in one way or another to the fiscal versus monetary policy debate. It is the kind of paper that overwhelms a discussant by its size and scope. So, to keep my task manageable, I will be selective and not try to touch every base that Karl touches. Still, that will leave me with plenty to do.

The organizers of this conference must have known that the only way to get me to raise my output above its natural rate was to hit me with a series of unanticipated shocks. This they did-with Karl's help. Originally, I was asked to be a discussant of a paper on the evolution of monetarism written by the man who invented the word. That sounded interesting. Then came the first unanticipated shock: I was told that the paper would really be about fiscal policy. Somehow that made me anticipate a paper full of Brunner-Meltzer type models with emphasis on asset substitutability and the financial aspects of fiscal operations. When the paper finally arrived (just a few days ago), I received my second unanticipated shock. I never imagined that Karl would try to resurrect the old AM/FM debate, today, in the age of VCRs, digital recordings, and cable TV. But he did!

Ironically, it was just this week that I lectured on the monetaristKeynesian debate in my graduate course at Princeton. In almost three hours of lecturing, I never once mentioned Friedman and Meiselman, Ando and Modigliani, Andersen and Jordan, Blinder and Solow, Goldfeld and Blinder, or any of the other parties to this debate. Apparently, Karl thinks that my graduate students were shortchanged. So I'd like to 
redress that first. Then I will turn to issues pertaining to the government budget constraint and to the Reagan-Barro equivalence theorem, where, I am happy to say, our disagreements are quite minor.

\section{The Intellectual Setting}

But first a brief word about the intellectual setting for this debate. Like McCallum (see Chapter 2), Karl reminisces about the bad old days in which Neanderthal Keynesians roamed the land, spreading the false word that money does not matter. McCallum even dates the Neanderthal period as lasting at least until 1965.

Funny, but I don't remember it that way at all. Maybe I'm just too young. But I started studying economics in 1963-the year the Friedman-Meiselman study was published-and grew up thinking that money mattered quite a lot, even though I was exposed to one Keynesian teacher after another and never saw a live monetarist until Leonall Andersen gave a guest lecture at MIT in 1970. My first college textbook was Paul Samuelson's fifth edition published in 1961, and therefore written in 1960 or 1959 , which by 1963 had been widely imitated. As I remember, my young, impressionable mind got the strong impression that money and monetary policy mattered quite a bit.

But Karl and Ben induced me to check my memory. So I dusted off my old Samuelson. Let me read you a few quotations. In Chapter 15, immediately after dismissing the crude quantity theory, Samuelson remarked:

"Few people are still alive who subscribe to the crude quantity theory, but we should not use its inadequacies to damn the whole idea that money can have important effects on macroeconomic magnitudes... The next few chapters will show how monetary policy does have an important influence on the total of spending." (p. 315)

Then on the very next page, he explained that a "sophisticated quantity theorist" does not believe that velocity is constant but claims instead that controlling the money supply will help to control national income. According to the Samuelson of 1961, "this is in agreement with almost any modern theory of income determination" (p. 316). The last sentence of the chapter entices students to read the next two chapters (on banking and central banking) with the words: "So from every point of view, the discussions in the ensuing chapters ... are of tremendous importance." (p. 316) 
In Chapter 18 Samuelson began the "Synthesis of Monetary Analysis and Income Analysis" with the words "Monetary analysis is seen to fit in well with the modern theory of income determination; the stage is set for stabilization policy-central bank monetary policies and government fiscal policies and government fiscal policies." (p. 366) (Notice who got first billing!) He then proceeded to outline the standard "Keynesian" transmission mechanism by means of interest rates and investment.

My question is a simple and rhetorical one: Can anyone reading this book have come away with the ideas that money is unimportant and monetary policy is impotent?

\section{Simple Correlations and Reduced Forms}

Up until a few years ago, I used to tell Princeton freshmen the story of how the Neanderthal Keynesians, with their stone-age view that money doesn't matter, were vanquished by the Cro-Magnon monetarists, with their equally silly view that fiscal policy doesn't matter. When I did so, I always put the story in the past tense, on the assumption that the issue was dead and buried. The tone was clearly: Thank God we don't argue about that any more.

Now, Karl wants us to exhume the body. Although I'm not sure I have penetrated his methodological discussion, he seems to defend simple reduced forms, or even simpler correlation coefficients, as the "right" way to test one broad class of hypotheses against another. As he puts it:

The "single equation with single variable" was the appropriate choice for an evaluation of a class of hypotheses seriously presented in textbooks and class teachings [p. 41]. Reliance on the correlation coefficient... is quite appropriate for the evaluation of the core-class addressed by Friedman and Meiselman [p. 43].

Let me try to explain what I think Karl means, using as my example the simplest version of the St. Louis equation. Then I'll say why I think he is wrong. Suppose that true model of the economy is Eq. (1) of Karl's paper:

$$
Y_{t}=k+a F_{t}+b M_{t}+e_{t}
$$

where $e$ includes quite a lot of things, some of which are at least partly forecastable. If $F, M$, and $e$ are all orthogonal random variables, then the variance of $Y$ is 


$$
\operatorname{Var}(Y)=a^{2} \operatorname{Var}(F)+b^{2} \operatorname{Var}(M)+\operatorname{Var}(e) .
$$

I think Karl wants to say that the "core-class" hypothesis of the CroMagnon monetarists was that $b^{2} \operatorname{Var}(M)$ is much bigger than $a^{2} \operatorname{Var}(F)$, so that movements of $M$ dominate movements of $Y$. Conversely, the core of the Neanderthal Keynesian view is that $a^{2} \operatorname{Var}(F)$ is much larger than $b^{2} \operatorname{Var}(M)$. With orthogonal data the simple correlation coefficients provide the data needed to discriminate between these two hypotheses, since in this model $r(Y, F)$ is proportional to $a \sigma(F)$, and $r(Y, M)$ is proportional to $b \sigma(M)$. This decomposition of $\operatorname{Var}(Y)$ even makes sense, because a high $r(Y, M)$ and a low $r(Y, F)$ would mean that monetary impulses dominate the movement of $Y$, and vice versa.

At some level I have sympathy with Karl's methodological point of view, since I do think that an economic model must consist both of a set of equations and a judgment about the nature of the dominant stochastic disturbances. But my sympathy is only skin deep.

One reason is trivial and obvious. If $F$ and $M$ covary in the data, the clean decomposition in (2) cannot be done. There is a covariance term that Cro-Magnons can attribute to monetary policy and Neanderthals can attribute to fiscal policy. Nothing in the data will adjudicate this dispute, which is more teleological than logical.

Another problem arises when policy is set purposefully. At the risk of some duplication, let me state that point as simply as possible, even though Karl has discussed it at length, modernizing it as I do to account for rational expectations. Goldfeld and I (1972) suggested that $M$ and $F$ are not whimsical random variables but may instead be deliberately manipulated to offset changes in $e$. If monetary policy fully offsets the expected value of $e$, then

$$
M_{t}=-(1 / b) E_{t-1} e_{t},
$$

and (1) becomes

$$
Y_{t}=k+a F_{t}+\left(e_{t}-E_{t-1} e_{t}\right) .
$$

If forecasts are pretty good, the innovation would have small variance, $r(Y, F)$ would be high, and regression (1) would yield a zero coefficient for $M$. Hence, Neanderthal Keynesians would be judged correct by Karl's criterion. Both F-M and A-J would have become fiscalists. And all because monetary policy was so effective.

On the other hand, if fiscal policy did the stabilizing and monetary policy was random, the corresponding equations would be 


$$
\begin{gathered}
F_{t}=-(1 / a) E_{t-1} e_{t}, \\
Y_{t}=k+b M_{t}+\left(e_{t}-E_{t-1} e_{t}\right) .
\end{gathered}
$$

Now $Y$ and $F$ would be uncorrelated, whereas $Y$ and $M$ are highly correlated, and a regression of the form (1) would assign a zero coefficient to fiscal policy. These are just the findings of F-M and A-J. Karl would judge the Cro-Magnon monetarists correct because fiscal stabilization was so effective.

But neither conclusion makes sense; neither finding implies that either policy tool is powerless to influence GNP. In (6) we have no way to estimate $a$ and in (4) we have no way to estimate $b$. In either case, purposeful policy reactions deny the econometrician the information he needs to estimate one of the multipliers.

Surely we all know by now that neither $a$ nor $b$ is zero, that both monetary and fiscal policy are from time to time used purposefully, and that many variables are omitted from (1). So why argue about which of two silly hypotheses is the sillier? I'd rather see the fossils of the FM/AM debate left in the grave.

\section{The Government Budget Constraint and Fiscal-Monetary Interactions}

I have much more favorable things to say about Karl's excellent discussion of the government budget constraint and the issues it raises. In fact, I think we see eye to eye almost totally-which makes both of us, I think, disagree with McCallum. By the way, I think that when Blinder and Solow agree so closely with Brunner and Meltzer, that's worth noting. Maybe we have hit on some deep truth! My capsule summary of the debate would differ in only minor ways from Karl's. It goes like this.

The paper Solow and I published in 1973 dealt with a simple case of fixed prices and fixed tax rates. It pointed out and explained the paradoxical result that a rise in government spending is more expansionary in the long run if the ensuing deficits are covered by issuing bonds than if they are covered by printing money-provided the system is stable under both financial policies. More importantly, perhaps, it showed that the likelihood of instability is far greater under bond financing than under money financing.

Notice that this is bad news for monetarism-not as theory but as policy-because the "bond-financed" case is essentially the monetarist policy rule of steady (in this case, zero) money growth. 
Though the details of our model left much to be desired, I think these basic findings have proven to be very robust. Brunner and Meltzer and Tobin and Buiter established parallel results in full-employment models with variable prices; Buiter, Pyle and Turnovsky, and others allowed both prices and output to vary. Other extensions opened the economy, allowed more assets, and so on.

None of these earlier contributions, however, dealt in a satisfactory way with rational expectations. Actually, I think it is impossible to do that, except in a totally arbitrary way. Let me explain why.

One problem posed by rational expectations is the Reagan-Barro equivalence theorem. If bonds are just congealed future taxes, then the wealth effects that lie at the heart of this analysis disappear. There is no stability issue because bond financing is just tax financing. And the relevant choice is between money finance and tax finance, not between money and bonds. Karl discusses this extensively and well. But let me defer it for the moment, for I have something else in mind.

In conjunction with any sort of forward-looking expectations, the government budget constraint sets up dynamic constraints across policy choices. To take a not very hypothetical example, suppose the current government raises spending and cuts tax rates, thereby opening up a deficit. Current and future governments are thereby obligated to do some combination of

(a) raising tax rates

(b) cutting spending

(c) printing money

(d) floating more bonds.

(This latter possibility can last forever only if the conditions for stability under bond finance hold; and they may not.) It is rational for people to know this, therefore, and to expect some combination of these events sometime in the future. But, as Karl points out, who knows when? And who knows which ones the government will choose?

In Barro's hands, rational expectations is interpreted to mean that tax cuts covered by debt today must lead to future tax increases of equal present value. In that case, under a host of other assumptions (see below), we get non-Ricardian equivalence, and current bond-financed tax cuts affect nothing. But that's only one of several possibilities.

Sargent and Wallace (1981) assume that if the economy is unstable under bond financing, the government will ultimately have to resort to money creation. Since rational expectations in a frictionless world effectively telescope the future back to the present, they conclude that tight money might be inflationary. But that's only a second possibility.

President Reagan and his crowd had a different form of rational expectations in mind. They argued that taking away the tax revenue today was 
the way to get spending down tomorrow. So far that idea has not worked very well. But who can say it was not a "rational" expectation, or that it was less rational than Barro's or Sargent and Wallace's.

My view on this issue is very similar to Karl's: who knows what or when? If a government opts for bond financing of deficits, which seems to be the default option (pardon the pun!), and it discovers that it has thereby put the economy on an unstable path, something will definitely have to give. The economy will not zoom off to either positive or negative infinity. Something will happen. But what? Sargent and Wallace gave us one possibility; another is that the economy will get a new government; yet another is that institutional changes will take place, altering the structure of the model.

Karl gets this analysis just right, I think. He is also right, in my judgment, to point to the tremendous uncertainty that this must cause in people's minds. When an individual has very diffuse priorities over what long-run government policy will be, it strikes me as plausible that his point estimates of future policy variables may have weak effects on his current decisions-which is just the opposite of what Barro and Sargent and Wallace assume. If this is so, then expectational issues, although deep and weighty, may not be of great empirical importance. I, of course, do not pretend to know that this is the case. I merely raise it as a possibility.

Another problem stems from diversity of expectations across individuals. If Barro thinks that current deficits will eventually lead to massive future taxes, if Sargent thinks they will eventually lead to a huge amount of money creation, and if Reagan thinks they will lead to huge future cuts in spending, and the economy will be stable under pure bond financing, then the economy may not converge to any rational expectations equilibrium at all, as Phelps and others have pointed out.

\section{4.a. Monetization}

I'd like to say one thing about the empirical aspects of the fiscal-monetary interaction. Following King and Plosser, Karl states that "There is . . no evidence for a contemporaneous relation between deficit and money creation in the U.S.A." (p. 98) That's what I used to think. But I found otherwise in a paper in this conference series two years ago. Let me try to reconcile the two views.

King and Plosser found no zero-order correlation between deficits and money growth over the 1953-82 period. I did several things differently. I used fiscal-year data and included off-budget items to get a more accurate measure of the budget deficit. I used bank reserves rather than the money supply to look directly at the monetization decision rather than at the money multiplier. And I took care to make the dimensions of vari- 
ables and their alignment in time consistent with the government budget constraint. Nonetheless, I also found no zero-order correlation between deficits and changes in bank reserves over the 1949-81 fiscal years.

But something quite different, and quite surprising, emerged when I allowed the monetization decision to depend on lagged inflation and lagged growth of real federal purchases: a strong and quite robust empirical relationship between deficits and changes in bank reserves emerged. At least over the 1961-81 period, the deficit was a significant determinant of monetization; but the fraction of the deficit that was monetized fell as either inflation or the growth of federal purchases rose. This empirical regularity survived most of my attempts to get rid of it, including adding other variables, shortening the sample period, differencing (à la Plosser and Schwert), and a Chow test for coefficient shifts.

In the end I changed my beliefs. I now think there is reasonably good evidence that larger deficits typically cause (in the Hume sense, not the Granger sense) faster growth of bank reserves in the United States. However, I should point out that the estimated fraction of the deficit that is monetized is never very large, and it gets negative when lagged inflation is high.

\section{Non-Ricardian Equivalence}

Before discussing Karl's discussion of Ricardian equivalence, I'd like to say a word about truth-in-naming. As we all should know by now, David Ricardo thoroughly discussed what is now called the Ricardian equivalence proposition-and rejected it. That does not mean that the equivalence proposition is false; Ricardo probably also believed in bleeding. But it does mean that we should stop calling it Ricardian. I propose that we call it the Reagan-Barro equivalence proposition.

When it comes to the substance of the issue, I feel relatively comfortable with Karl's discussion. I would have changed the emphasis in some places: for example, I attach more importance to the problem of corner solutions at zero bequests. Especially in a growing economy in which children are, on average, better off than their parents and in which bequests in human form are substantial, I suspect that many optimizers would like to leave a negative bequest but cannot. A tax cut or a rise in social security benefits now, balanced by future taxes on our children, is one way to accomplish this.

Karl correctly characterizes the empirical evidence on the equivalence theorem as quite mixed. And he expresses some surprise that the data are not more decisive, because he finds the Barro-Reagan proposition 
implausible on a priori grounds. I am also surprised. The Barro-Reagan view has proven much harder to reject than I thought. The evidence adduced to date really is too mixed and, as previously noted, too ideologically correlated to resolve the issue.

In fact, a recent paper by Benjamin, Kochin, and Meador suggests that many of the empirical tests of equivalence may be entirely beside the point. Their basic argument is consistent with Barro's work on optimal debt policy and can be summarized as follows.

Tax rates are not arbitrary but are purposefully manipulated by government to minimize deadweight loss over time. As Barro pointed out, the optimizing government will want to smooth tax rates relative to expenditures. Under certainty, the optimal tax rate is constant through time. But when there is uncertainty, the optimal tax rate will evolve as a random walk, following the current estimate of the present value of expenditures.

One implication of this kind of optimizing behavior, pointed out by Benjamin et al., is that the rational expectations consumption function becomes Keynesian. This is easy to see. The rational expectations consumption function appealed to by Barro is farsighted and forwardlooking:

$$
C_{t}=k\left[\sum_{s=0}^{\infty} \frac{{ }_{t} Y_{t+s}}{(1+r)^{s}}-\sum_{s=0}^{\infty} \frac{{ }_{t} T_{t+s}}{(1+r)^{s}}\right] .
$$

In the Barro-Reagan story, any arbitrary change in current $T_{t}$ is balanced by changes in the opposite direction in some future ${ }_{t} T_{t+s}$ 's of equal present value. Hence, the tax term does not change, and neither does $C_{t}$.

But if $T_{t}$ is a random walk, then current $T$ (not current spending) is the best estimator of any future $T_{t+s}$. So a rise in $T_{t}$ will be interpreted by consumers as indicating a rise in the permanent levels of government spending and taxation. They will therefore reduce their consumption accordingly. So current taxation will have strong Keynesian effects on current consumption.

Note the strong parallels between this argument and the one I made earlier about St. Louis equations. Both econometric procedures make sense if the government policy instruments are set whimsically. But both can give seriously misleading results if the government acts purposefully.

\section{Conclusion}

In sum, I disagree most emphatically with Karl's attempt to resurrect and legitimize the old reduced form approach, but I agree with most of what 
he says about the government budget constraint and the non-Ricardian equivalence theorem. Two out of three is not bad!

Since Karl is labeled a monetarist and I am labeled a Keynesian, and since neither one of us shuns our label, maybe this wide-ranging agreement suggests that the labels are obsolete and possibly even dysfunctional. I, for one, would be happy to declare the monetarist-Keynesian debate over today, right here in St. Louis. What an appropriate place!

\section{References}

Barro, R. J. 1974. Are government bonds net wealth? Journal of Political Economy 82: $1095-1117$.

Benjamin, D. K., L. Kochin, and M. Meador. n.d. Observational equivalence of rational and irrational consumers if taxation is efficient. Unpublished manuscript.

Blinder, A. S. and R. M. Solow. 1973. Does fiscal policy matter? Journal of Public Economics 2: 319-37.

Brunner, K. and A. H. Meltzer. 1976. An aggregative theory for a closed economy. In Monetarism, ed., J. Stein. Amsterdam: North-Holland.

Buiter, W. 1976. Capacity constraints, government financing and the short-run and long-run effects of fiscal policy. Unpublished manuscript.

Friedman, M. and D. Meiselman. 1963. The relative stability of monetary velocity and the investment multiplier in the United States, 1897-1958. In Stabilization Policies. Englewood Cliffs, N.J.: Prentice-Hall.

Goldfeld, S. M. and A. S. Blinder. 1972. Some implications of endogenous stabilization policy. Brookings Papers on Economic Activity 3: 585-640.

King, R. G. and C. I. Plosser. 1984. Money, deficits and inflation. Presented at Carnegie-Rochester Conference Series on Public Policy.

Pyle, D. H. and S. J. Turnousky. 1976. The dynamics of government policy in an inflationary economy: An 'intermediate run' analysis. Journal of Money, Credit and Banking 8: 411-37.

Samuelson, P. A. 1961. Economics: An Introductory Analysis. New York: McGraw-Hill.

Sargent, T. J. and N. Wallace. 1981. Some unpleasant monetarist arithmetic. Federal Reserve Bank of Minneapolis Quarterly Review 6: 1-17.

Tobin, J. and W. Buiter. 1976. Long run effects of fiscal and monetary policy on aggregate demand. In Monetarism, ed. J. Stein. Amsterdam: North-Holland. 